\title{
HUBUNGAN MEDIA KOMUNIKASI K3 DENGAN PENGETAHUAN DAN SIKAP PENGGUNAAN ALAT PELINDUNG DIRI PADA KARYAWAN BAGIAN PRODUKSI
}

\author{
Lusha Ayu Astari ${ }^{1}$, Denny Ardyanto ${ }^{2}$ \\ ${ }^{1,2}$ Departemen Keselamatan dan Kesehatan Kerja Fakultas Kesehatan Masyarakat Universitas \\ Airlangga \\ lushaayu@gmail.com
}

\begin{abstract}
One of the prevention of workplace accidents is to use a personal protective equipment (PPE), but there are still many workers who do not want to use it for various reasons. OHS communication media is one way to improved knowledge and attitudes of workers used PPE. The purpose of this study was to know the relationship between the number of OHS communication media that respondents received with the knowledge and attitude of the PPE. The study design was cross-sectional. Determination of the number of respondents used total sampling methods and get 48 respondents. Data collected by interview used a questionnaire and observation with the checklist that refers to the Workplace Safety and Health for Industrial Marine. The result of knowledge level about PPE of 88\% of respondents has been good and 65\% of respondents had a positive attitude to the use of PPE. OHS media communication that given by company include in enough category (73\%) and the result of analysis OHS communication media with knowledge about PPE used contingency coefficient has a value of 0.412, while analysis OHS communication media with the attitude factor has a value 0,204. In conclusion, the number of OHS communications media received by employees with the level of knowledge have a moderate relationship and the number of OHS communication media received by employees with the attitude of the PPE have a weak relationship.
\end{abstract}

Keywords: OHS, PPE, media, communications, attitude, knowledge.

\begin{abstract}
ABSTRAK
Salah satu upaya pencegahan kecelakaan kerja adalah dengan menggunakan alat pelindung diri (APD) namun masih banyak pekerja yang tidak mau menggunakannya karena berbagai alasan. Media komunikasi K3 menjadi salah satu upaya untuk meningkatkan pengetahuan dan sikap pekerja terhadap penggunaan APD. Tujuan penelitian ini adalah untuk mengetahui hubungan antara jumlah media komunikasi K3 yang diterima responden dengan pengetahuan dan sikap penggunaan APD. Rancangan penelitian ini adalah cross sectional. Penentuan jumlah responden penelitian ini menggunakan metode total sampling dan didapatkan responden sebesar 48 orang. Pengumpulan data dilakukan dengan wawancara menggunakan kuesioner untuk mendapatkan informasi mengenai karakteristik responden, tingkat pengetahuan tentang APD, dan sikap penggunaan APD. Observasi dengan menggunakan checklist dilakukan untuk mengetahui jumlah media komunikasi K3 yang diberikan oleh perusahaan mengacu pada Workplace Safety and Health for Industrial Marine. Hasil dari tingkat pengetahuan tentang APD yang dimiliki oleh $88 \%$ responden sudah baik dan $65 \%$ responden sudah bersikap positif pada penggunaan APD. Media komunikasi K3 yang diberikan perusahaan termasuk kategori cukup (73\%). Hasil analisis media komunikasi K3 dengan pengetahuan menggunakan koefisien kontingensi memiliki nilai 0,412 , sedangkan hasil analisis media komunikasi K3 dengan sikap penggunaan APD menggunakan koefisien kontingensi memiliki nilai 0,204. Kesimpulan penelitian ini adalah jumlah media komunikasi K3 yang diterima karyawan dengan tingkat pengetahuan memiliki hubungan yang sedang dan jumlah media komunikasi K3 yang diterima karyawan dengan sikap penggunaan APD memiliki hubungan yang lemah.
\end{abstract}

Kata kunci: K3, APD, media, komunikasi, sikap, pengetahuan 


\section{PENDAHULUAN}

Keselamatan dan Kesehatan Kerja (K3) bertujuan memberi perlindungan kepada tenaga kerja, karena tenaga kerja merupakan aset yang harus dipelihara dan dijaga keselamatannya. Penyebab kecelakaan kerja berdasarkan teori domino H.W. Heinrich (1930) dalam Ramli (2010), digolongkan menjadi dua diantaranya adalah tindakan tidak aman dari manusia (unsafe action), misalnya tidak mau menggunakan alat keselamatan dalam bekerja, melepas alat pengaman, atau bekerja sambil bergurau. Tindakan ini dapat membahayakan dirinya atau orang lain yang dapat berakhir dengan kecelakaan. Selain itu adalah faktor kondisi tidak aman (unsafe condition) yakni kondisi di lingkungan kerja baik alat, material atau lingkungan yang tidak aman dan membahayakan. Sementara menurut penelitian Santoso (2004) 80-85\% kecelakaan disebabkan oleh faktor manusia diantaranya adalah kemampuan tenaga kerja dan ketidakseimbangan psikologi, kurang terampil, kurangnya pengetahuan, serta motivasi menurun.

Upaya untuk mengatasi tindakan tidak aman (unsafe action) dan kondisi tidak aman (unsafe condition) yang merupakan penyebab kecelakaan kerja yaitu dengan pengendalian secara teknik, pengendalian secara administratif, dan dengan menggunakan alat pelindung diri. Pengendalian secara teknik adalah cara pengendalian yang paling efektif dan menjadi alternatif pertama yang dianjurkan, sedangkan alat pelindung diri merupakan garis pertahanan yang terakhir (the last line of defense) (Siswanto, 1991). Namun pada kenyataannya cara pengendalian risiko seperti rekayasa teknik sulit diimplementasikan karena berbagai faktor. Oleh sebab itu penggunaan APD masih diharuskan dan diwajibkan untuk digunakan sebagai upaya menekan residual risk (Tarwaka, 2008).

Penggunaan APD akan terlaksana dengan baik pula apabila adanya dukungan dari perusahaan melalui pengendalian administratif, salah satunya dengan penyediaan APD, membuat peraturan terkait kewajiban menggunakan APD, serta menyediakan media komunikasi K3 untuk meningkatkan pengetahuan dan kesadaran karyawan akan pentingnya penggunaan APD. Pengendalian bahaya menggunakan APD tidak akan maksimal jika pekerjanya sendiri tidak menggunakan karena tidak tahu dan tidak mau tahu tenang APD tersebut.

Kegagalan memakai alat pelindung diri dengan benar merupakan perilaku tidak aman yang dapat memicu terjadinya insiden dalam bentuk hubungan langsung antara pekerja dengan sumber bahaya. Tahun 2012 ILO mencatatat angka kematian dikarenakan kecelakaan dan penyakit akibat kerja (PAK) sebanyak 2 juta kasus setiap tahun. Penelitian di desa Mrisi, kabupaten Grobogan menemukan bahwa masalah utama pada gangguan fungsi paru pada pekerja adalah kebiasaan tidak menggunakan APD di tempat kerja. Hal ini menunujukan penggunaan APD dalam bekerja menjadi penting untuk melindungi bukan hanya dari kecelakaan kerja namun juga menjaga kesehatan para pekerja agar terhindar dari penyakit akibat kerja dan dapat terus bekerja dengan baik (Yulaekah, 2007).

Lawrence Green (1980) dalam Notoatmodjo (2007) mengemukakan bahwa tindakan seseorang ditentukan oleh faktor predisposisi yaitu pengetahuan dan sikap; faktor pendukung yaitu ketersediaan, kenyamanan, dan pelatihan; serta faktor pendorong yaitu peraturan dan pengawasan. Penggunaan APD juga ikut dipengaruhi beberapa faktor yang membuat seseorang tidak mau menggunakan APD yaitu kurangnya pengetahuan, rasa tidak nyaman, serta kurangnya sosialisasi dan media komunikasi tentang K3 sehingga banyak karyawan yang melanggar dalam hal penggunaan APD. Oleh karena itu perlunya peran aktif manajemen dalam mensosialisasikan media komunikasi K3 pada karyawan agar dapat meningkatkan pengetahuan dan sikap penggunaan APD. Hal ini dapat diperjelas dengan penelitian yang dilakukan oleh Gumelar dan Denny (2017) menunjukkan bahwa ada hubungan safety talk dengan tingkat pengetahuan pekerja di Unit Maintenance PT. Holcim Indonesia Tbk.

Undang-undang Nomor 1 tahun 1970 tentang Keselamatan Kerja bab $\mathrm{X}$ tentang Kewajiban Pengurus pada pasal 14 poin b menyatakan bahwa "Pengurus diwajibkan memasang dalam tempat kerja yang dipimpinnya sетиa gambar keselamatan kerja yang diwajibkan dan semua bahan pembinaan lainnya, pada tempat-tempat yang mudah dilihat dan terbaca menurut petunjuk pegawai pengawas atau ahli keselamatan kerja", hal ini menjelaskan kewajiban pemilik usaha untuk 
memberikan media komunikasi K3 terhadap tenaga kerjanya sehingga dapat membentuk dan meningkatkan pengetahuan pekerja akan bahaya kerja maupun penggunaa APD dalam kerja (Departemen Hukum dan PerundangUndangan, 1970).

Pada penelitian yang dilakukan oleh Widianti (2008) dalam Amin (2013) suatu perusahaan pabrik gula menunjukan terjadi 17 kecelakaan kerja yang menimpa tenaga kerja di bagian produksi selama musim giling 20052006. Penyebab kecelakaan kerja tersebut adalah perilaku tenaga kerja yang tidak aman karena kurangnya pengetahuan tentang potensi bahaya yang terdapat di tempat kerjanya, hal ini juga didukung karena kurangnya informasi dan media komunikasi yang disediakan perusahaan sebagai sarana meningkatkan pengetahuan karyawannya.

Media adalah suatu sarana komunikasi yang efektif untuk menyampaikan pesan karena dapat memberikan pengaruh yang besar pada perilaku seseorang, bahkan seseorang cenderung menjadikan media yang ada di sekitarnya sebagai sumber informasi dan timbul kecenderungan meniru perilaku model yang diangkat oleh media (Soehoet, 2003).

Menurut Edgar Dale (1969) dalam Arsyad (2010) perbandingan efektivitas media terhadap pemahaman sasaran secara verbal adalah sebanyak $1 \mathrm{x}$, secara visual sebanyak $3,5 \mathrm{x}$, dan kombinasi keduanya mencapi $6 \mathrm{x}$. Maka dari itu penyampaian media komunikasi K3 yang beragam jenisnya diharapkan dapat menjadi sarana meningkatkan pengetahuan dan sikap penggunaan APD.

PT. Braja Musti merupakan perusahaan swasta nasional yang bergerak di bidang jasa konstruksi. Penelitian ini dilakukan pada proyek pembuatan jalan di terminal peti kemas Surabaya. Penggunaan alat berat dan pekerjaan yang memiliki risiko bahaya yang tinggi tidak dapat dihindari dalam proses produksinya. Bahaya yang dapat terjadi di tempat kerja sangat tinggi seperti risiko jatuh, keadaan lingkungan yang suhunya cukup tinggi, intensitas dan kadar debu yang tinggi, serta perilaku karyawan yang tidak menggunakan alat pelindung diri saat bekerja.

Menurut pihak manajemen jumlah kecelakaan kerja yang terjadi selama kurun waktu 2013 - 2014 adalah sebanyak 7 kecelakaan kerja di bagian produksi. Menurut pihak manajemen sejauh ini perusahaan belum menyediakan kebutuhan akan media informasi
K3 yang lebih variatif untuk meningkatkan kesadaran karyawan akan pentingnya penggunaan alat pelindung diri saat bekerja.

Tujuan penelitian ini adalah mengetahui hubungan antara jumlah media komunikasi keselamatan dan kesehatan kerja dengan pengetahuan dan sikap penggunaan alat pelindung diri.

\section{METODE}

Penelitian ini dilihat dari segi pengambilan data termasuk penelitian observasional. Apabila ditinjau dari segi waktu, penelitian ini termasuk penelitian cross sectional yakni observasi pada suatu saat dengan obyek yang diukur hanya sekali saja dan pengukuran variabel subyek.

Penelitian ini dilakukan di PT. Braja Musti yang merupakan salah satu perusahaan yang bergerak di bidang jasa konstruksi yang sebelumnya belum pernah dilakukan penelitian seperti ini. Pelaksanaan penelitian dimulai dari bulan April 2015 sampai dengan bulan Januari 2016 yang meliputi kegiatan perizinan, pnyusunan proposal dan penulisan hasil penelitian. Sementara itu, pengambilan data dilakukan pada bulan Desember 2015.

Populasi pada penelitian ini adalah seluruh karyawan bagian produksi yang ada di PT. Braja Musti sebesar 48 orang. Cara penentuan sampel pada penelitian ini adalah dengan metode total populasi sehingga didaptkan sampel pada penelitian ini adalah semua karyawan bagian produksi PT. Braja Musti sebesar 48 orang karyawan bagian produksi.

Variabel independent media komunikasi keselamatan kesehatan kerja yang diterima responden. Sedangkan variabel dependent pada penelitian ini adalah tingkat pengetahuan APD dan sikap penggunaan APD.

Pengumpulan data dilakukan melalui lembar kuesioner pada karyawan untuk mengetahui tingkat pengetahuan dan sikap penggunaan APD karyawan sedangkan untuk analisis media komunikasi K3 yang tersedia dilakukan dengan observasi menggunakan checklist, serta dilakukan pula wawancara untuk mengetahui kebijakan perusahaan terkait media keselamatan kesehatan kerja yang diterapkan di perusahaan.

Pengolahan data pengetahuan untuk setiap pertanyaan dengan jawaban benar diberi nilai 1, sedangkan untuk jawaban salah diberi skor 0 . Kemudian, dibuat presentasenya 
dengan membagi skor yang didapat dengan skor maksimal kemudian dikalikan seratus persen. Kriteria tingkat pengetahuan terbagi atas baik (76\%-100\%), cukup (56\%-75\%), dan kurang $(<56 \%)$ (Arikunto, 2006).

Pengolahan data untuk sikap adalah dengan skala model Likert dengan mengubah skor yang diperoleh responden menjadi nilai $\mathrm{T}$. Responden diberikan pernyataan positif dan negatif yang dijawab sesuai dengan persepsi dan pandangan responden yang menyatakan setuju atau tidak setuju atas pernyataan yang diberikan tersebut. Apabila nilai T lebih besar dari nilai mean maka sikap responden dikategorikan positif dan apabila nilai $\mathrm{T}$ lebih kecil dari nilai mean maka sikap responden dikategorikan negatif (Azwar, 2013).

Pengolahan data untuk jumlah media komunikasi K3 yang diterapkan perusahaan maupun yang diterima karyawan dilakukan dengan menghitung jumlah media komunikasi K3 yang ada di perusahaan kemudian dibagi dengan total media komunikasi K3 yang ada pada acuan Workplace Safety and Health for Industrial Marine sebanyak 15 jenis. Kemudian, dibuat persentasenya dan hasilnya dikategorikan sebagai capaian penerapan media komunikasi K3. Kategorinya adalah sangat baik (86\%-100\%), baik (75\%-85\%), cukup (60\%-74\%), kurang (45\%-59\%), dan sangat kurang $(<44 \%)$.

Data yang sudah melalui pengolahan data akan dianalisis secara univariat untuk melihat frekuensi dan bivariat menggunakan uji koefisien kontingensi untuk mengetahui kuat hubungan antara media komunikasi keselamatan kesehatan kerja dengan pengetahuan dan sikap penggunaan APD. Data disajikan dalam bentuk narasi dan tabel.

\section{HASIL}

\section{Gambaran Umum Perusahaan}

PT. Braja Musti merupakan perusahaan kontraktor di Surabaya yang bergerak di bidang jasa konstruksi dan bangunan. PT. Braja Musti memberikan pelayanan dalam melaksanakan pembangunan infrastruktur, gedung bertingkat, pembuatan jalan, saluran drainase kota, bendungan, dan sebagainya. Seiring berjalannya waktu PT. Braja Musti terus berusaha memberikan dan mengembangkan inovasi dalam pemberian pelayananannya.

PT. Braja Musti berdiri pada tahun 2008 di Surabaya dan memiliki beberapa anak perusahaan. Sebelum menjadi PT. Braja Musti di awal dekade 1990 perusahaan ini berdiri sebagi CV. Tri Tunggal juga di Surabaya. Kemudian, CV. Tri Tunggal terus berkembang besar dan memiliki beberapa spesialisasi khusus sehingga pada tahun 2008 dibentuklah perseroan terbatas (PT) dengan nama Braja Musti sebagai induk perusahaan yang menaungi enam anak perusahaan dengan spesialisasi masing-masing dan sebagai upaya pengembangan usaha.

PT. Braja Musti banyak mengerjakan proyek yang berhubungan dengan kelautan seperti pembuatan dermaga, pembuatan bendungan, pengerasan dan pembuatan jalan di terminal peti kemas, serta berbagai proyek lainnya, maka dari itu PT. Braja Musti menerapkan K3 dalam perusahaannya karena menyadari besarnya risiko yang dihadapi pada proses pekerjaan yang dilakukan. Manajemen PT. Braja Musti menyadari pentingnya K3 sebagai cara untuk meningkatkan produktivitas perusahaan dan mencegah besarnya kerugian yang ditanggung karena kecelakaan kerja sehingga komitmen untuk membentuk budaya K3 sudah ada dan diwujudkan dengan sering menjalin kerjasama dengan owner proyek ataupun kontraktor lain untuk membangun sistem manajemen K3 yang baik selama pengerjaan proyek. Pelatihan dan seminar sebelum pengerjaan proyek juga sering diadakan untuk karyawan. Hal tersebut dilakukan dengan harapan pada saat melakukan pengerjaan proyek minim bahkan nihil terjadinya kecelakaan kerja.

Komitmen lain dari pihak manajemen PT. Braja Musti diwujudkan salah satunya dengan memfasilitasi penyampaian K3 pada seluruh karyawan melalui media komunikasi. Media

komunikasi yang diberikan berpedoman pada Workplace Safety and Health for Industrial Marine. Selain itu, adanya dukungan penuh manajemen dan direksi untuk selalu berusaha membentuk lingkungan yang mendukung terbentuknya budaya K3 di perusahaan.

\section{Karakteristik Responden}

Karakteristik responden pada penelitian ini diperoleh dari data kuesioner yang diberikan pada responden yang terdiri dari umur, tingkat pendidikan, dan masa kerja. Responden penelitian ini adalah total populasi karyawan bagian produksi atau karyawan lapangan PT. Braja Musti yang hadir dan 
bersedia mengisi kuesioner pada saat penelitian berlangsung.

\section{Karakteristik Responden Berdasarkan Usia}

Umur responden yang dimaksud pada penelitian ini merupakan umur karyawan

\begin{tabular}{|c|c|c|}
\hline Usia & Frekuensi & Persentase (\%) \\
\hline $17-25$ & 5 & 10 \\
$26-35$ & 12 & 25 \\
$36-45$ & 18 & 38 \\
$46-55$ & 8 & 17 \\
$56-65$ & 5 & 10 \\
\hline Total & 48 & 100 \\
\hline
\end{tabular}

Berdasarkan tabel 1 didapatkan karyawan bagian produksi PT. Braja Musti berada pada rentang umur 17-65 tahun dimana rentang umur tersebut termasuk dalam rentang umur yang produktif. Distribusi umur responden paling banyak berada pada kategori umur 36-45 tahun (38\%) yang berarti pekerja umumnya ada pada rentang umur yang sudah matang dalam bekerja.

\section{Karaktersitik Responden Berdasarkan \\ Masa Kerja}

Tabel 2.Karakteristik Responden Berdasarkan Masa Kerja Tahun 2015

\begin{tabular}{|c|c|c|}
\hline Masa Kerja & Frekuensi & Persentase (\%) \\
\hline$<1$ th & 0 & 0 \\
$1-3$ th & 10 & 21 \\
$>3$ th & 38 & 79 \\
\hline Total & 48 & 100 \\
\hline
\end{tabular}

Berdasarkan Tabel 2 menunjukkan bahwa karyawan bagian produksi di PT. Braja Musti memiliki masa kerja sebagian besar di atas 3 tahun yaitu sebanyak 38 orang (79\%) hal ini menunjukan sebagian besar pekerja memiliki pengalaman yang cukup dalam bekerja dan mengenali lingkungan kerjanya. bagian produksi dihitung sejak karyawan tersebut lahir sampai pada tahun dilakukan penelitian ini berdasarkan hasil kuesioner. Berikut ini merupakan data mengenai karakteristik responden berdasarkan usia.
Masa kerja responden yang dimaksud adalah rentang waktu karyawan bekerja sejak pertama kali bekerja di PT. Braja Musti sampai pada saat penelitian dilakukan. Masa kerja kemudian dikategorikan menjadi tiga menurut Nurlatif (2006) yaitu (1) masa kerja baru (<1tahun); (2) masa kerja sedang (1-3tahun); dan (3) masa kerja lama (>3tahun). Berikut ini adalah data mengenai karakteristik responden berdasarkan masa kerja:

\section{Karakteristik Responden Berdasarkan Tingkat Pendidikan}

Tingkat pendidikan pada penelitian ini adalah jenjang pendidikan formal terakhir yang ditempuh oleh responden sampai pada saat penelitian berlangsung. Adapun data mengenai karakteristik responden berdasarkan tingkat pendidikan adalah sebagai berikut.

Tabel 3. Karakteristik Responden Berdasarkan Tingkat Pendidikan Tahun 2015

\begin{tabular}{|c|c|c|}
\hline Tngkat Pendidikan & Frekuensi & Persentase (\%) \\
\hline SD & 6 & 13 \\
SMP & 10 & 21 \\
SMA/SMK & 23 & 48 \\
Diploma/Sarjana & 9 & 19 \\
\hline Total & 48 & 100 \\
\hline
\end{tabular}

Berdasarkan Tabel 3 dapat diketahui bahwa tingkat pendidikan karyawan bagian produksi di PT. Braja Musti hampir 


\section{Identifikasi Tingkat Pengetahuan Responden tentang APD}

Tingkat pengetahuan reponden tentang alat pelindung diri didapatkan dari lembar kuesioner yang diisi oleh responden yang Tabel 4. Tingkat Pengetahuan responden tentang APD tahun 2015

\begin{tabular}{|c|c|c|}
\hline Tingkat Pengetahuan & Frekuensi & Persentase (\%) \\
\hline Baik & 42 & 88 \\
Cukup & 5 & 10 \\
Kurang & 1 & 2 \\
\hline Total & 48 & 100 \\
\hline
\end{tabular}

Berdasarkan tabel 4 dapat dilihat bahwa tingkat pengetahuan responden hampir seluruhnya sudah baik. Hal ini menunjukan bahwa sebagian besar karyawan bagian produksi memiliki cukup informasi mengenai APD dan mengetahui tentang APD yang mereka gunakan. menyetujui inform consent yang diberikan. Hasil distribusi berdasarkan tingkat pengetahuan tentang APD adalah sebagai berikut

\section{Identifikasi Sikap Responden terhadap} Penggunaan APD

Sikap responden tentang penggunaan APD merupakan bentuk pandangan karyawan tentang bagaimana penggunaan dan APD yang baik dan benar. Cara mengetahui sikap penggunaan APD pada responden digunakan alat bantu berupa kuesioner. Berikut ini adalah distribusi data tentang sikap responden

Tabel 5. Sikap Responden tentang Penggunaan APD tahun 2015

\begin{tabular}{|c|c|c|}
\hline Kategori Sikap & Frekuensi & Persentase (\%) \\
\hline Positif & 31 & 65 \\
Negatif & 17 & 35 \\
\hline Total & 48 & 100 \\
\hline
\end{tabular}

Tabel 5 menunjukan responden yang memiliki sikap positif lebih dari setengah jumlah seluruh responden yaitu berjumlah $65 \%$. Hal ini menunujukan sebagian karyawan bagian produksi memiliki sikap yang baik dalam menggunakan APD. Namun masih banyak juga karyawan yang bersikap negatif dimana hal ini kurang sesuai dengan hasil penilaian tingkat pengetahuan yang sebagian besar adalah baik, ternyata tidak sepenuhnya didukung dengan sikap positif karyawan bagian produksi tentang penggunaan APD.

\section{Identifikasi Jumlah Media Komunikasi K3} Perusahaan

Tabel 6. Media Komunikasi yang diberikan PT. Braja Musti pada Karyawannya tahun 2014-2015

\begin{tabular}{|c|c|c|}
\hline Kriteria & Frekuensi & Persentase (\%) \\
\hline Safety Promotion (4) & 2 & 13 \\
Small Group Meeting (2) & 2 & 13 \\
Safety Information (5) & 4 & 27 \\
Others form (2) & 1 & 7 \\
Emergency Responce (2) & 2 & 13 \\
\hline Total (15) & 11 & 73 \\
\hline
\end{tabular}

Tabel 6 menunjukan jumlah media komunikasi K3 yang disediakan perusahaan adalah sebanyak 11 jenis media komunikasi K3 dari total keseluruhan berdasarkan pedoman Workplace Safety and Health for Industrial Marine adalah 15 jenis. Hal ini menunjukan bahwa perusahaan telah memenuhi sebagian besar jenis media sudah diberikan oleh PT. Braja Musti kepada karyawannya didapatkan dengan bantuan lembar checklist dan kuesioner dengan bertanya langsung pada supervisor lapangan. Lembar checklist terdiri dari 5 kategori didasarkan atas standar Workplace Safety and Health for Industrial Marine. Hasil capaian media komunikasi K3 berdasarkan pada ketersediaan jenis media komunikasi K3 yang kemudian dijumlahkan dan diprosentasekan capaiannya. Berikut adalah data media komunikasi yang diberikan perusahaan. 
komunikasi K3 yang semestinya disediakan dan apabila dikategorikan persentase jumlah jenis media komunikasi $\mathrm{K} 3$ sebesar $73 \%$ yang termasuk dalam kategori cukup, sehingga masih perlu peningkatan dari perusahaan.

\section{Identifikasi Jumlah Media Komunikasi yang diterima Karyawan}

Observasi dan wawancara dilakukan dengan lembar checklist dan kuesioner yang sama yang diberikan pada supervisor lapangan untuk mengetahui jumlah media komunikasi K3 yang diterima tiap karayawan. Hal ini diperlukan untuk mengetahui capaian media komunikasi K3 yang sudah diberikan perusahaan pada karayawannya.

Tabel 7. Media Komunikasi yang diterima Karyawan PT. Braja Musti pada tahun 2014-2015

\begin{tabular}{|c|c|c|}
\hline Capaian & Frekuensi & Persentase (\%) \\
\hline Baik & 2 & 4 \\
Cukup & 31 & 65 \\
Kurang & 11 & 23 \\
Sangat Kurang & 4 & 8 \\
\hline Total & 48 & 100 \\
\hline
\end{tabular}

Berdasarkan distribusi pada tabel 7 didapatkan capaian media komunikasi K3 yang diterima karyawan paling banyak adalah pada kategori cukup yaitu 31 orang $(65 \%)$. Hal ini menunjukan sebagian besar karyawan sudah menerima media komunikasi K3 yang diberikan perusahaan. Namun, masih ada karyawan yang merasa sangat kurang mendapat media komunikasi K3 dari perusahaan, meskipun jumlahnya sedikit hal ini perlu mendapat perhatian khusus penyebab karyawan tersebut sangat kurang mendapatkan media komunikasi K3 karena keselamatan dan kesehatan kerja merupakan hal yang penting,

Tabel 8. Tabel Silang Jumlah Media Komunikasi K3 yang diterima Karyawan PT. Braja Musti dengan Tingkat Pengetahuan APD

\begin{tabular}{|c|c|c|c|c|}
\hline \multirow{2}{*}{ Media K3 } & \multicolumn{4}{|c|}{ Pengetahuan APD } \\
\cline { 2 - 5 } & Baik & Cukup & Kurang & Total \\
\hline Baik & 2 & 0 & 0 & 2 \\
Cukup & 29 & 1 & 1 & 31 \\
Kurang & 9 & 2 & 0 & 11 \\
Sangat Kurang & 2 & 2 & 0 & 4 \\
\hline Total & 42 & 5 & 1 & 48 \\
\hline
\end{tabular}

Berdasarkan tabel 8 di atas dapat dilihat bahwa paling banyak adalah karyawan yang mendapatkan media komunikasi K3 dalam jumlah cukup dan memiliki tingkat pengetahuan yang sudah baik.

Kemudian dilakukan uji statistik dengan menggunakan uji koefisien kontingensi untuk mengetahui kuat hubungan antara media komunikasi K3 yang diterima karyawan dengan pengetahuan tentang APD. Hasil dari uji tersebut didapatkan nilai $=0,412$ dimana nilai tersebut lebih mendekati 0 . Sehingga baik bagi individu karyawan maupun perusahaan.

\section{Hubungan Jumlah Media Komunikasi K3 dengan Tingkat Pengetahuan APD}

Setelah mengetahui capaian jumlah media komunikasi $\mathrm{K} 3$ yang diterima karyawan selanjutnya dihubungkan dengan tingkat pengetahuan APD karyawan untuk mengetahui kuat hubungan pada kedua variabel tersebut. Berikut ini adalah data tabulasi silang antara jumlah media komunikasi K3 yang diterima karyawan dengan tingkat pengetahuan APD karyawan. 


\section{Hubungan Jumlah Media Komunikasi dengan Sikap Penggunaan APD}

Capaian jumlah media komunikasi K3 yang diterima karyawan dihubungkan dengan sikap penggunaan APD karyawan juga untuk mengetahui kuatnya hubungan antara kedua Tabel 9. Tabel Silang Jumlah Media Komunikasi K3 yang diterima Karyawan PT. Braja Musti dengan Sikap Penggunaan APD

\begin{tabular}{|c|c|c|c|}
\hline \multirow{2}{*}{ Media K3 } & \multicolumn{3}{|c|}{ Sikap Penggunaan APD } \\
\cline { 2 - 4 } & Baik & Cukup & Total \\
\hline Baik & 2 & 0 & 2 \\
Cukup & 21 & 10 & 31 \\
Kurang & 6 & 5 & 11 \\
Sangat Kurang & 2 & 2 & 4 \\
\hline Total & 31 & 17 & 48 \\
\hline
\end{tabular}

Berdasarkan tabel 9 distribusi sikap positif terhadap penggunaan APD terbanyak ditemukan pada karyawan yang mendapatkan jumlah media komunikasi K3 cukup yaitu berjumlah 21 orang. Namun untuk sikap negatif karyawan juga terbanyak pada jumlah media komunikasi yang cukup yang diterima karyawan yaitu sebanyak 10 orang. Kemudian, dilakukan uji statistik dengan menggunakan coefficient contingency untuk mengetahui kuat hubungan antara media komunikasi K3 dengan sikap penggunaan APD dan didapatkan nilai $=$ 0,204 dimana nilai tersebut lebih mendekati 0 sehingga dapat diartikan bahwa kuat hubungan antara jumlah media komunikasi yang diterima responden dengan sikap penggunaan APD karyawan adalah lemah, sesuai dengan kategori (Sugiono, 2004). Hal ini menunjukan jumlah media komunikasi K3 dengan sikap penggunaan APD memiliki hubungan yang lemah yang berarti banyaknya jumlah media komunikasi K3 yang diterima karyawan belum dapat mempengaruhi sikap karyawan untuk dapat bersikap positif pada penggunaan APD.

\section{PEMBAHASAN}

\section{Karakteristik Responden}

Responden pada penelitian ini sebanyak 48 orang karyawan bagian produksi yang bekerja di PT. Braja Musti, Surabaya. Pekerja paling muda dalam populasi yang bekerja di PT. Braja Musti berusia 19 tahun, sedangkan pekerja paling tua berusia 60 tahun. Usia tersebut dalam Undang-undang Nomor 13 Tahun 2003 tentang Ketenagakerjaan adalah termasuk usia produktif untuk bekerja (Presiden Republik Indonesia, 2003). variabel. Berikut ini merupakan data tabulasi silang antara jumlah media komunikasi K3 yang diterima karyawan dengan sikap penggunaan APD karyawan.
Faktor usia berpengaruh pada pengalaman hidup seseorang termasuk pengalaman yang berhubungan dengan K3 . Manusia pasti pernah hampir mengalami kecelakaan atau kesakitan dalam. Hal tersebut dapat menjadi suatu pengalaman sehingga dapat dijadikan usaha untuk mencegah kejadian yang tidak diingankan (Tarwaka, 2008).

Frekuensi usia karyawan PT. Braja Musti didominasi rentang usia 36 tahun sampai dengan 45 tahun. Usia yang mendominasi tersebut sudah termasuk pada usia matang yang termasuk sudah cukup untuk memiliki pengalaman. Usia pekerja dapat menjadi penyebab kecelakaan kerja. Pada pekerjaan yang memerlukan banyak tenaga kerja biasanya dipilih tenaga kerja yang masih muda karena fisiknya masih kuat namun tenaga kerja usia muda biasanya masih penuh emosi, ceroboh, dan kurang pengalaman sehingga sering menimbulkan tindakan berbahaya. Pada pekerja usia tua lebih dapat dipercaya, lebih berhati-hati dan lebih menyadari akan bahaya kecelakaan yang dapat timbul saat bekerja (Suma'mur, 2014).

Menurut penelitian Kirwan (2015) menyatakan tidak terdapat hubungan antara umur dengan penggunaan APD. Sedangkan menurut Poedjawijatna (2004) dalam penelitian Megawati (2011) menunjukkan adanya kecenderungan mengenai semakin bertambahnya umur seseorang maka semakin bertambah pula pengetahuannya, hal ini menunjukan umur lebih berpengaruh pada pengetahuan daripada sikap, dalam hal ini adalah tentang APD. 
Responden yang mempunyai masa kerja lebih dari 3 tahun berjumlah lebih dari separuh jumlah keseluruhan responden. Masa kerja ini menurut Handoko dalam Nurlatif (2006), merupakan masa kerja yang termasuk dalam kategori lama. Handoko dalam Nurlatif (2006) membagi masa kerja berdasarkan kategori, masa kerja kategori baru yaitu $0-1$ tahun, masa kerja kategori sedang yaitu $>1-3$ tahun, dan masa kerja kategori lama yaitu $>3$ tahun.

Menurut Ambarwati (2013), masa kerja akan dapat menambah pengalaman yang didapatkan oleh seseorang dimana semakin lama masa kerja seseorang maka akan lebih mampu untuk menyesuaikan diri dengan pekerjaannya dan lingkungannya. Pengalaman kerja yang dimiliki seseorang menjadi faktor penting yang dapat mempengaruhi terjadinya kecelakaan kerja dan upaya pencegahan kecelakaan kerja itu sendiri.

Seseorang yang memiliki masa kerja yang masuh sedikit maka biasanya mudah melakukan kesalahan dalam bekerja yang dapat mengakibatkan terjadinya kecelakaan kerja. Kesalahan yang terjadi dapat disebabkan karena kurangnya pengalaman serta kecakapan seseorang tersebut dalam menyesuaikan pekerjaannya. Notoatmodjo (2003) menyatakan dengan masa kerja yang semakin banyak maka semakin baik juga pengalaman seseorang mengenai pekerjaannya dan risiko bahaya yang dihadapi dalam bekerja. Namun, apabila masa kerja terlalu banyak dapat juga membuat seseorang menjadi selalu percaya diri sehingga tidak menggunakan APD pada saat bekerja. Hal tersebut dilakukan karena merasa sudah tahu dengan jenis pekerjaannya serta risiko yang akan terjadi. Padahal secara tidak sadar kecelakaan kerja dapat terjadi kepada siapapun dan di manapun.

Tingkat pendidikan responden sebagian besar adalah SMA/SMK sederajat. Hal tersebut menunjukan sebagian besar responden sudah memiliki tingkat pendidikan yang cukup tinggi dimana dengan tingkat pendidikan yang tinggi tersebut diharapkan resonden dapat lebih baik pula dalam menerima berbagai informasi K3 tentang APD di perusahaan. Tingkat pendidikan merupakan salah satu faktor pembentuk persepsi, sikap, dan perilaku seseorang. Menurut Priatna \& Umar (1991) bahwa pendidikan seseorang mempengaruhi cara berpikir dalam menghadapi pekerjaan, demikian juga dalam menerima latihan kerja praktik maupun teori, termasuk diantaranya cara pencegahan kecelakaan ataupun cara menghindari bila terjadi kecelakaan. Maka, tingkat pendidikan responden berpengaruh pada tingkat pengetahuan yang juga merupakan dasar pembentukan sikap dan perilaku seseorang.

\section{Identifikasi Jumlah Media Komunikasi K3}

Menurut Ramli (2010), bentuk komunikasi ada berbagai jenis, baik lisan maupun tulisan yang dapat berhubungan dengan kepentingan K3. Semakin banyak jenis media komunikasi yang diberikan maka akan semakin mudah diterima informasi yang ingin disampaikan untuk membentuk suatu perilaku.

Dhasa (2011), menyebutkan Workplace Safety and Health for Marine Industries menetapkan pedoman jenis media komunikasi yang disediakan perusahaan untuk karyawannya meliputi safety promotion, small group meetings, safety information, others form of consultation and communication, emergency response prosedur. Hal tersebut merupakan peraturan yang diambil dari WHO Council (2005) yang kemudian jenis media komunikasi tersebut diadaptasi oleh PT. Braja Musti untuk diterapkan dalam perusahaan menyampaikan K3 pada karyawannya. Berdasarkan tabel 6 Jumlah media komunikasi yang sudah diterapkan berjumlah 11 media dan masuk dalam kategori cukup. Hal ini tentunya perlu peningkatan penerapan media komunikasi dari perusahaan dengan tujuan untuk meningkatkan pengetahuan dan sikap penggunaan APD karyawannya sebagai upaya pencegahan kecelakaan kerja.

Berdasarkan tabel 7 lebih dari separuh jumlah reponden mendapatkan media komunikasi K3 dalam kaegori cukup dan hanya sebagian kecil yang mendapatkan media komunikasi K3 dalm kategori baik. Hal ini menunjukan masih kurangnya media komunikasi K3 yang disampaikan pada keseluruhan karyawan, padahal media komunikasi K3 dapat meberikan informasi tentang APD yang diperlukan karyawan untuk membentuk perilaku dan budaya kerja yang baik. Menurut Azwar (2013), media masa elektronik maupun media cetak sangat besar pengaruhnya terhadap pembentukan opini dan kepercayaan seseorang. Pemberian informasi melalui media masa mengenai sesuatu hal diharapkan akan dapat memberikan landasan kognitif baru bagi terbentuknya sikap. 
Menurut Fajar (2009), tujuan komunikasi diantaranya adalah perubahan sikap, perubahan pendapat, perubahan perilaku, dan perubahan sosial. Komunikasi dapat disampaikan dengan baik melalui bantuan media komunikasi agar dapat diterima dengan baik sebagai informasi bagi pihak lain, dalam hal ini media komunikasi K3 dapat menjadi cara mensosialisasikan penggunaan APD yang baik untuk meningkatkan pengetahuan aryawan yang diharapkan dapat berpengaruh pada sikap dan perilaku penggunaan APD degan baik. Kurang baiknya komunikasi dan keterbatasan informasi banyak mengakibatkan kecelakaan kerja sehingga dapat mempengaruhi kinerja karyawan.

\section{Hubungan Jumlah Media Komunikasi dengan Tingkat Pengetahuan APD}

Berdasarkan hasil penelitian pada tabel 4 tingkat pengetahuan responden tentang APD diketahui sebagian besar ada pada kategori baik $(88 \%)$. Pengetahuan merupakan hasil dari proses penginderaan manusia atau hasil tahu terhadap suatu objek melalui indera yang dimiliki manusia seperti mata, hidung, telinga, dan sebagainya. Pengetahuan yang didasari pengalaman akan mempengaruhi seseorang untuk berperilaku lebih baik (Notoatmodjo, 2010).

Berdasarkan tabel 8 persentase responden tertinggi terdapat pada jumlah media yang diterima karyawan dalam kategori cukup dan tingkat pengetahuan yang baik. Hal ini menunjukan jumlah media yang cukup yang diberikan perusahaan sudah dapat memberikan tingkat pengetahuan yang baik pada sebagian besar karyawan. Berdasarkan uji statistik yang dilakukan menunjukan hubungan antara jumlah media komunikasi yang diterima karyawan dengan tingkat pengetahuan APD dimana nilai coefficient contingency didapatkan sebesar 0,412 dimana nilai tersebut mendekati 0 yang apabila mengacu pada kategori Sugiono (2004) dapat ditarik kesimpulan bahwa hubungan antar jumlah media komunikasi K3 dengan tingkat pengetahuan responden adalah sedang, sehingga media komunikasi K3 yang diterima karyawan saat ini tidak cukup kuat untuk meningkatkan tingkat pengetahuan karyawan tentang APD.

Edgar Dale (1969) dalam Putra (2013) menyatakan dimana penyampaian media yang beragam dapat menjadi sarana untuk meningkatkan pengetahuan. Kurang kuatnya hubungan media komunikasi K3 dengan tingkat pengetahuan responden perusahaan menunjukan perusahaan perlu meningkatkan dan menambah jumlah serta jenis media untuk lebih meningkatkan lagi pengetahuan karyawannya, penambahan media ini tidak dapat hanya sekali dilakukan tapi harus secara rutin agar dapat membetuk perilaku K3 yang baik dan menjadi budaya di perusahaan.

Menurut Nursalam (2001), pengetahuan dipengaruhi beberapa faktor, yaitu pendidikan, pengalaman, umur, dan sumber informasi. Hal ini sejalan dengan penelitian ini dimana media komunikasi K3 yang dalam kategori cukup saja memiliki hubungan yang sedang pada tingkat pengetahuan responden, sehingga perlu adanya perhatian lebih dari perusahaan untuk mengadakan dan menyampaikan informasi kepada karyawan sebagai salah satu upaya pencegahan kecelakaan kerja.

\section{Hubungan Jumlah Media Komunikasi dengan Sikap Penggunaan APD}

Berdasarkan hasil penelitian yang disajikan pada tabel 5 sikap penggunaan APD karyawan PT. Braja Musti 65\% karyawan bersikap positif terhadap penggunaan APD. Notoatmodjo (2010) menyatakan bahwa dalam menentukan suatu sikap yang utuh terdapat beberapa faktor yang memegang peranan penting yaitu pengetahuan, pikiran, keyakinan, dan emosi. Apabila pengetahuan seseorang terhadap suatu objek itu baik maka sikap seseorang pada objek tersebut cenderung akan ikut baik.

Berdasarkan tabel 9 jumlah sikap positif terbesar ditemukan pada kategori media cukup, sehingga berdasarkan hal tersebut dapat dideskripsikan bahwa jumlah media komunikasi yang diterima karyawan yang berada pada kategori cukup sebanding dengan munculnya sikap positif penggunaan APD. Namun, jumlah sikap penggunaan APD yang negatif juga muncul tertinggi pada jumlah media komunikasi yang cukup, hal tersebut merancukan hubungan media komunikasi K3 sebagai pembentuk sikap, maka dari itu dilakukan uji statistik dengan menggunakan coefficient contingency untuk mengetahui kuat hubungan antar media komunikasi K3 dan sikap penggunaan APD dan didapatkan nilai koefisien sebesar 0,204 dimana nilai tersebut mendekati 0 yang dapat diartikan bahwa hubungan antara jumlah media komunikasi 
yang diterima responden dengan sikap penggunaan APD karyawan adalah lemah, bahkan lebih lemah dari nilai yang didapat oleh faktor tingkat pengetahuan. Hal ini menunujukan kuat hubungan antara jumlah media komunikasi K3 yang diterima karyawan saat ini dengan sikap penggunaan APD adalah lemah dan tidak dapat membawa perubahan berarti pada sikap karyawan terhadap penggunaan APD.

Sikap merupakan kumpulan gejala dalam merespon stimulus atau objek, sehingga sikap melibatkan pikiran, perasaan, perhatian dan gejala kejiwaan lain (Notoatmodjo, 2010). Sikap dapat muncul bukan hanya dari tingkat pengetahuan yang ada pada individu namun juga dapat muncul akibat adanya panutan yang dicontoh di perusahaan, misalnya pimpinan, kepala regu, atau mandor. Menurut Gunawan (2013), pimpinan memiliki peran yang besar dalam mempengaruhi sikap dan perilaku aman maupun perilaku tidak aman. Sikap juga dipengaruhi oleh tata nilai, kesadaran, emosi, motivasi, persepsi, risiko, pengalaman masa lalu dan sebagainya.

Cara lain untuk membentuk sikap di perusahaan sesorang dapat menggunakan reward dan punishment, namun PT. Braja Musti secara personal belum menerapkan hal ini dengan tegas dan terprosedur. Reward dan punishment ini juga akan memotivasi pekerja dalam menggunakan APD pada saat bekerja (Nasrullah dan Suwandi, 2014).

Azwar (2013), menyatakan bahwa faktor yang mempengaruhi pembentukan sikap antara lain berasal dari media masa dimana media masa memiliki tugas pokok dalam penyampaian informasi, media masa membawa pesan yang berisi sugesti yang dapat mengarahkan opini seseorang. Pesan dan sugesti yang dibawa oleh informasi tersebut apabila cukup kuat akan memberi dasar afektif dalam menilai sesuatu hal sehingga terbentuklah arah sikap tertentu. Hal tersebut tidak sesuai dengan hasil penelitian di PT. Braja Musti dimana kuat huungan media komunikasi K3 dengan pembentukan sikap positif pada karyawannya adalah lemah. Hasil ini dapat disebabkan oleh karena karena sikap berkaitan dengan karakterstik individu yang dipengaruhi berbagai variabel seperti motif, sifat kepribadian yang saling berinteraksi satu sama lain dan kemudian berinteraksi dengan faktor lingkungan yang menentukan sikap seseorang. Dengan demikian, penarikan kesimpulan mengenai sikap individu kurang tepat jika mengharapkan adanya hubungan langsung yang nyata antara media komunikasi K3 dengan sikap penggunaan APD.

\section{KESIMPULAN}

Usia responden merupakan usia produktif dengan masa kerja sebagian besar pada kategori masa kerja lama dan juga sebagian besar responden memiliki tingkat pendidikan setara SMA/SMK.

Sebagian besar responden memiliki tingkat pengetahuan dengan kategori baik tentang alat pelindung diri dan lebih dari separuh responden memiliki sikap yang positif tentang penggunaan alat pelindung diri.

Jumlah media komunikasi K3 yang disediakan perusahaan berada pada kategori cukup dan lebih dari separuh responden mendapatkan media komunikasi K3 yang cukup juga.

Kuat hubungan antara jumlah media komunikasi K3 yang diterima responden dengan tingkat pengetahuan tentang APD adalah yang sedang dan kuat hubungan antara jumlah media komunikasi yang diterima responden dengan sikap penggunaan APD responden memiliki hubungan yang lemah.

\section{DAFTAR PUSTAKA}

Ambarwati, D. R. 2013. Faktor yang Berhubungan dengan Safety Behaviour pada Pekerja Mekanik di Workshop PT. Mandala karya Prima Nunukan Kalimantan Timur. Skripsi, Universitas Airlangga, Surabaya.

Amin, N. R. 2013. Pengembangan Media Keselamatan Kerja di PT. Pabrik Gula Candi Baru Sidoarjo Bagian Produksi Sebagai Upaya Pencegahan Kecelakaan Kerja. Skripsi, Universitas Airlangga, Surabaya.

Arikunto, S. 2006. Prosedur Penelitian suatu Pendekatan Paraktek. Jakarta: Rineka Cipta.

Arsyad, A. 2010. Media Pembelajaran. Jakarta: Rajawali Pers.

Azwar, S. 2013. Sikap Manusia: Teori dan Pengukurannya, Yogyakarta: Pustaka Pelajar. doi: 10.1038/cddis.2011.1.

Departemen Hukum dan PerundangUndangan. 1970. Undang-Undang Nomor 1 Tahun 1970 Tentang Keselamatan Kerja.

Dhasa, D. S. P. 2011. Identifikasi Penerapan 
Komunikasi K3 sebagai Upaya Pencegahan Kecelakaan Kerja (Studi Foreman di PT.PAL Indoneisia). Skripsi, Universitas Airlangga, Surabaya. Diakses dari: http://repository.unair.ac.id/23069/.

Fajar, M. 2009. Ilmu Komunikasi Teori \& Praktek. 1st ed. Yogyakarta: Graha Ilmu.

Gumelar, F. dan D. A. 2017. Hubungan Kepatuhan Dan Pengetahuan Tentang Apd Dengan Safety Talk Di Unit Maintenance Pt. Holcim Indonesia Tbk. Journal of Public Health Research and Community Health Development, 1(2), pp. 154-164.

Gunawan. 2013. Safety Leadership : Building an Excellent Operation. Jakarta: Dian Rakyat.

Kirwan, D. 2015. Hubungan Pengetahuan, Sikap, dan Penyediaan APD dengan Penggunaan APD di PG. Candi Baru. Surabaya: Universitas Airlangga.

Megawati, I. A. 2011. Hubungan Predisposing, Enabling, dan Reinforcing Faktor dengan Perilaku K3 dalam Upaya Mencegah Kecelakaan Kerja Pada Tenaga Laboratorium Rumah Sakit Bhayangkara Surabaya. Skripsi, Universitas Airlangga, Surabaya. Diakses dari: http://repository.unair.ac.id/22917/.

Nasrullah, M. dan Suwandi, T. 2014. Hubungan Antara Knowledge, Attitude, Practice Safe Behavior Pekerja dalam Upaya untuk Menegakkan Keselamatan dan Kesehatan Kerja. The Indonesian Journal of Occupational Safety and Health, 3(1), pp. 82-93.

Notoatmodjo, S. 2003. Pendidikan Perilaku Kesehatan, Jakarta: Rineka Cipta.

Notoatmodjo, S. 2007. Promosi Kesehatan dan Ilmu Perilaku. Jakarta: Rineka Cipta.

Notoatmodjo, S. 2010. Ilmu Perilaku Kesehatan. Cetakan Pertama. Jakarta: Rineka Cipta.

Nurlatif, V. 2006. Hubungan Lama Bekerja dengan Kapasitas Vital Paru Operator SPBU Sampangan, Semarang.Skripsi,Universitas Negeri Semarang. Diakses dari: https://lib.unnes.ac.id/688/.

Nursalam, P. 2001. Pendekatan Praktis Metodologi Riset Keperawatan. Jakarta: Sagung Seto.

Presiden Republik Indonesia. 2003. UndangUndang No.13 Tahun 2003 tentang Ketenagakerjaan.
Priatna, B. L. \& Umar, F. A. 1991. Pencegahan Kecelakaan Kerja pada Sektor Informal. Upaya Kesehatan Kerja Sektor Informal di Indonesia. Jakarta: Departemen Kesehatan RI.

Putra, S. R. 2013. Desain Belajar Mengajar Kreatif Berbasis Sains. Yogyakarta: Diva Press.

Ramli, S. 2010. Sistem Manajemen Keselamatan dan Kesehatan Kerja (OHSAS 18001). Jakarta: PT Dian Rakyat.

Santoso, G. 2004. Ergonomi Manusia, Peralatan, dan Lingkungan. Sidoarjo: Prestasi Pustaka.

Siswanto, A. 1991. Alat Pelindung Diri. Balai Hiperkes dan Keselamatan Kerja Jawa Timur: Depnaker.

Soehoet, A. H. 2003. Dasar-dasar Jurnalistik. Jakarta: IISIP Press.

Sugiono. 2004. Statistika untuk Penelitian. Cetakan keenam. Bandung: Penerbit Alfabeta.

Suma'mur. 2014. Higiene Perusahaan dan Kesehatan Kerja (HIPERKES). 2 ed. Jakarta: Sagung Seto.

Tarwaka. 2008. Keselamatan dan Kesehatan Kerja: Manajemen dan implementasi K3 di Tempat Kerja. Surakarta: Harapan Press.

WHO Council. 2005. Workplace Safety and Health Manual for Marine Industries. Singapura: ASMI.

Yulaekah, S. 2007. Paparan Debu Terhirup dan Gangguan Fungsi Paru pada Pekerja Industri Batu Kapur (Studi di Desa Mrisi Kecamatan Tanggungharjo Kabupaten Grobogan). Tesis, Universitas Diponegoro Semarang. 